\title{
PENYATUAN KALENDER ISLAM: MENDIALOGKAN WUJÛD AL-HILÂL DAN VISIBILITAS HILAL
}

\author{
Susiknan Azhari \\ Fakultas Syariah dan Hukum UIN Sunan Kalijaga Yogyakarta \\ Jalan Marsda Adisucipto Yogyakarta-Indonesia \\ E-mail: siknanazmi@yahoo.com
}

\begin{abstract}
Unification of the Islamic Calendar: A Dialogue on Wujûd al-Hilâl and the Visibility of Hilâl. Within the vocabulary of the Islamic calendar, particularly in Indonesia, the terms al-Hilâl and the sighting or "visibility" of the hilal (imkân al-ru'yah) are recognised. Wujûd al-hilâl is a creative synthesis or half way between ijtimâ' (qabl al-ghurûb) and the theory of the visibility of the hilâl or, in other words, half way between pure hisab (calculating the hilâl) and ruyah (the sighting of hilâl). Therefore, for the theory of wujûd al-hilâl, the method used in starting the first day and a new month on the Islamic calendar is not merely the process of the occurrence of astronomical conjunctions but also considering the position of hilâl at sunset. Meanwhile, the visibility of hilâl is a construction of theories that which are sourced from the experience of observers. As a result, various typologies are created. In order to unite both concepts, an assertive and continuous dialogue is required.
\end{abstract}

Keywords: hilâl, hisâb, rujyah, mațlac

\begin{abstract}
Abstrak: Penyatuan Kalender Islam: Mendialogkan Wujûd al-Hilâl dan Visibilitas Hilal. Dalam khazanah pemikiran kalender Islam, khususnya di Indonesia, dikenal istilah wujûd al-hilâl dan visibilitas hilal (imkân al-ru’yah). Kehadiran wujûd al-hilâl merupakan sintesis kreatif atau jalan tengah antara teori ijtimấ (qabl al-ghurûb) dan teori visibilitas hilal atau jalan tengah antara hisab murni dan rukyat murni. Oleh karena itu, bagi teori wujûd al-hilâl metode yang digunakan dalam memulai tanggal satu bulan baru pada kalender Islam tidak semata-mata proses terjadinya konjungsi tetapi juga mempertimbangkan posisi hilal saat matahari terbenam. Sementara itu visibilitas hilal adalah bangunan teori yang bersumber dari pengalaman para pengamat. Sehingga melahirkan bermacam-macam tipologi. Untuk memadukan keduanya diperlukan dialog yang asertif dan berkelanjutan.
\end{abstract}

Kata Kunci: hilal, hisab, rukyat, matlak

\section{Pendahuluan}

Kalender atau biasa disebut almanak atau penanggalan telah menjadi bagian penting dalam kehidupan seharihari dalam masyarakat. Bisa dibayangkan tanpa kalender kita akan kebingungan menentukan janji pertemuan, membuat program kerja suatu organisasi, bahkan aktivitas kenegaraan. Pada awalnya, kehidupan masyarakat sangat sederhana. Kemudian perkembangan kehidupan masyarakat kian menjadi lebih kompleks maka diperlukan adanya sistem kalender yang pasti untuk mengatur kegiatan yang akan dilakukan. Kehadiran kalender Islam bagi umat Islam sangat diperlukan karena terkait dengan persoalan ibadah, seperti puasa Ramadan, Idul Fitri, dan Idul Adha. Namun dalam realitasnya, kalender Islam masih beragam sehingga mengakibatkan perbedaan dalam

Naskah diterima: 21 Februari 2013, direvisi: 30 Mei 2013, disetujui untuk terbit: 7 Juni 2013. menentukan awal Ramadan dan Syawal. Bukti konkret perbedaan Idul Fitri 1432 dan awal Ramadan 1433 yang hingga kini masih menyisakan persoalan. ${ }^{1}$ Begitu pula keberlakuannya bersifat lokal sehingga masih sering terjadi perbedaan dalam menentukan Idul Adha antara Saudi Arabia dan negara-negara Islam lainnya, seperti kasus Idul Adha $1431 \mathrm{H}$ yang lalu antara Indonesia dan Saudi Arabia. ${ }^{2}$ Secara teoretis perbedaan akan terulang kembali pada awal Ramadan 1434/2013, awal Ramadan 1435/2014, dan

1 Perbedaan Idul Fitri $1432 \mathrm{H}$ berbeda dengan peristiwa sebelumnya. Pada tahun sebelumnya, lebih tenang dan santun, namun perbedaan Idul Fitri tahun ini terkesan kurang elegan dan kurang bijak. Apalagi dalam sidang isbat cenderung menjadi forum penghakiman dan truth claim. Baca Media Indonesia, Jumat, 2 September 2011, h. 1 dan Media Indonesia, Sabtu, 3 September 2011, h. 17. Baca juga Agus Purwanto, "Sidang Itsbat sudah Tidak Relevan", dimuat majalah Suara Muhammadiyah, No. 19/Th. Ke-96, 1-15 Oktober 2011, h. 28-30.

${ }^{2}$ Baca "Pemerintah Putuskan Idul Adha 17 November", dimuat Koran Tempo, Selasa, 9 November 2010, h. A7. 
Idul Adha 1435/2014. ${ }^{3}$ Karena itu kehadiran kalender Islam yang terintegrasi sangat dinantikan.

\section{Sejarah Kalender Islam}

Encyclopaedia Britannica menjelaskan bahwa sistem kalender yang berkembang di dunia sejak zaman kuno sampai era modern, yaitu: (1) Kalender Sistem Primitif, (2) Kalender Barat, (3) Kalender Cina, (4) Kalender Mesir, (5) Kalender Hindia, (6) Kalender Babilonia, (7) Kalender Yahudi, (8) Kalender Yunani, (9) Kalender Islam, dan (10) Kalender Amerika Tengah. ${ }^{4}$ Pada kesempatan ini yang menjadi fokus kajian adalah kalender Islam atau biasa diistilahkan dengan Islamic Calendar. Tokoh penggagas kalender Islam adalah Khalifah 'Umar ibn al-Khaththâb. ' Gagasan ini muncul ketika 'Umar ibn al-Khaththâb menjadi khalifah memperoleh surat dari Abû Mûsâ al-Ash'arî, Gubernur Kuffah yang menyampaikan, "Sesungguhnya telah sampai kepadaku beberapa surat dari khalifah tetapi surat-surat itu tidak ada tanggalnya."

Peristiwa tersebut direspons positif oleh 'Umar ibn alKhaththâb, kemudian mengumpulkan para sahabat yang ada di Madinah untuk membahas kalender Islam. Pada saat musyawarah berkembang beragam pendapat tentang permulaan kalender Islam. ${ }^{6}$ Akhirnya, musyawarah yang dipimpin oleh Amîr al-Muiminîn sepakat memutuskan dasar permulaan kalender Islam adalah peristiwa hijrah Nabi Saw. dari Mekah ke Madinah. Dalam khazanah Islam, kalender ini dikenal dengan Tầrîh Ishthilâhâ, Tầrikh Hijrah, ${ }^{7}$ kalender hisab alâmah, ${ }^{8}$ dan kalender hisab 'adadî.' Sementara itu para penulis Eropa menyebutnya

\footnotetext{
${ }^{3}$ Selengkapnya baca T. Djamaluddin, Astronomi Memberi Solusi Penyatuan Ummat, (Jakarta: LAPAN, 2011), h. 30.

${ }^{4}$ Anonim, Encyclopaedia Britannnica, vol. 5, (London: William Bentom Publisher, 1965), h. 611. Baca juga Akram Hasan al-Halbî, AlTaqwîm Dirâsah li al-Taqwîm wa al-Târîkh, cet. I, (Lubnân: al-Masâdir, 14311/1991), h. 39-49. Perhatikan pula Muhammad Muhammad Fayad, Al-Taqwîm, cet. II, (al-Qâhirah: Nahdet Misrr, 2003), h. 20-35.

${ }^{5}$ Muhammad Muhammad Fayad, Al-Taqwîm, h. 20-35.

${ }^{6}$ Pendapat-pendapat dimaksud yaitu: (a) ada yang berpendapat sebaiknya permulaan kalender Islam adalah tahun kelahiran Rasulullah Saw.; (b) ada yang berpendapat sebaiknya permulaan kalender Islam dimulai sejak Nabi Muhammad Saw. diangkat menjadi rasul; (c) ada yang berpendapat sebaiknya permulaan kalender Islam dimulai dari peristiwa Isra dan Mikraj; (d) ada yang berpendapat sebaiknya permulaan kalender Islam dimulai dari wafat Rasululullah Saw.; dan (e) 'Ali ibn Abî Tâlib berpendapat sebaiknya permulaan kalender Islam dimulai dari hijrah nabi (dari Mekah ke Madinah). Lihat http:// id.wikipedia.org, akses pada tanggal 22 Oktober 2011, pukul 11.47 WIB.

${ }^{7}$ Haji Md. Khair Haji Md. Taib, Takwim Hijriah Khairiah, (Bangi: Penerbit Universiti Kebangsaan Malaysia, 1987), cet. I, h. 12.

${ }^{8}$ Jamaluddin Abdur Razik, Al-Taqwîm al-Qamarî al-Islâmî alMuwahhad, (Rabat: Marsam, 2004), h. 32-33.

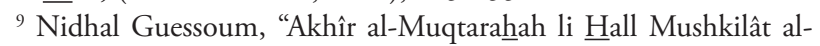

kalender aritmatik atau kalendar tabular. Sistem kalender Islam ini masih sederhana karena untuk keperluan administrasi semata, belum mempertimbangkan posisi hilal kaitannya dengan ritual keagamaan.

Perjalanan kalender Islam berkembang sesuai perkembangan peradaban Islam. Cyril Glasse melaporkan bahwa kalender Islam pada masa dinasti Fatimiah mengalami penyempurnaan dengan mempertimbangkan aspek astronomis. Hal ini dilakukan oleh Jenderal Jauhar setelah selesai mendirikan Kairo pada tahun 359 H/969 M. ${ }^{10}$

Pada masa kini, kalender Islam muncul dengan beragam corak, seperti Kalender Muhammadiyah, Almanak PB NU, Taqwim Standar Indonesia (Kementerian Agama RI), Almanak Menara Kudus, Almanak Jawatan Kemajuan Islam Malaysia, Takwim Ummul Qurra, dan Takwim Jamahiriya. Masing-masing kalender tersebut memiliki metode yang berbeda dalam penentuan awal bulan kamariah. Akibatnya tidak jarang terjadi perbedaan dalam menetapkan awal bulan Kamariah, khususnya Ramadan, Syawal, dan Zulhijah. Untuk lebih jelasnya perhatikan tabel berikut ini.

Idul Fitri di Indonesia 2000-2012 11

\begin{tabular}{cccc}
\hline Tahun & Lama Puasa & Perayaan & Hari/Tanggal \\
\hline 2001 & 29 & Serempak & Ahad, 16-12-2001 \\
\hline 2002 & $29 / 30$ & Berbeda & $\begin{array}{c}\text { Kamis/Jum'at, } \\
5 / 6-12-2002\end{array}$ \\
\hline 2003 & 29 & Serempak & Selasa, 25-11-2003 \\
\hline 2004 & 29 & Serempak & Ahad, 14-11-2004 \\
\hline 2005 & 29 & Serempak & Kamis, 3-11-2005 \\
\hline 2006 & $29 / 30$ & Berbeda & $\begin{array}{c}\text { Senin/Selasa, } \\
23 / 24-10-2006\end{array}$ \\
\hline 2007 & $29 / 30$ & Berbeda & $\begin{array}{c}\text { Jum'at/Sabtu, } \\
12 / 13-10-2007\end{array}$ \\
\hline 2008 & 30 & Serempak & Rabu, 1-10-2008 \\
\hline 2009 & 29 & Serempak & Ahad, 20-9-2009 \\
\hline
\end{tabular}

Taqwîm al-Islâmî”, dalam Nidhal Guessoum dan Mohammad Odeh, Applications of Astronomical Calculations to Islamic Issues, cet. I, (Abu Dhabi: ICOP, EAS \& CDR, 2007), h. 88.

${ }^{10}$ Selengkapnya baca Cyril Glasse, Ensiklopedi Islam, terjemahan Ghufran A. Mas'adi, cet. II, (Jakarta: PT. RajaGrafindo Persada, 1999), h. 205 .

${ }^{11}$ Tabel di atas memperlihatkan perbedaan terjadi antara Muhammadiyah, NU, dan Pemerintah. Dalam realitasnya, perbedaan tidak hanya tiga kelompok di atas, seperti kasus Idul Fitri 2008 meliputi: Ahad, 28 September 2008 = Al-Muhdlor Tulungagung, Senin, 29 September 2008 = Tarikat Naqsyabandiyah, Selasa, 30 September 2008 = An-Nadlir dan HTI, Rabu, 1 Oktober 2008 = Muhammadiyah, NU, dan Pemerintah, dan Jumat, 3 Oktober 2008 = Sekar Kandhi Sumenep, Kelompok Rasuli Probolinggo, Aboge Banyumas. Idul Fitri 1433 tidak terjadi perbedaan. Namun, awal Ramadan 1433 terjadi perbedaan sehingga lama usia Ramadan berbeda. 


\begin{tabular}{cccc}
\hline 2010 & 29 & Serempak & Jum'at, 10-9-2009 \\
\hline 2011 & $29 / 30$ & Berbeda & $\begin{array}{c}\text { Selasa/Rabu, } \\
\text { 30/31-9-2011 }\end{array}$ \\
\hline 2012 & $29 / 30$ & Serempak & Ahad, 19 Agustus 2012 \\
\hline
\end{tabular}

(Sumber: diolah dari dokumen pribadi)

\section{Hilal, Hisab-Rukyat, dan Kalender Islam}

Munculnya perbedaan dalam penetapan awal bulan Kamariah disebabkan tiga hal penting, yaitu: pengertian hilal, metode untuk mengetahui hilal, dan anggitan kalender Islam. Tiga hal ini berkelindan, tidak dapat dipisahkan antara satu dengan lainnya. Di sinilah diperlukan adanya ijtihad-kolektif-asertif.

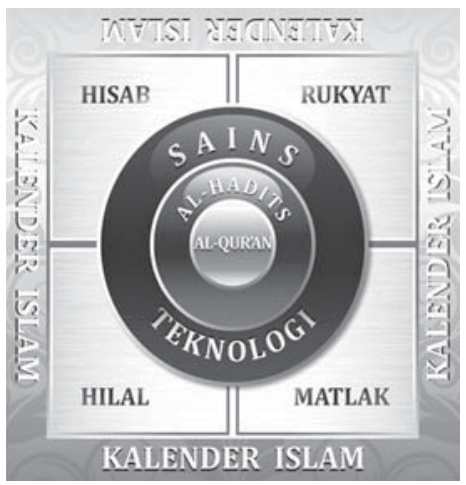

Pelbagai literatur klasik maupun kontemporer telah membahas persoalan hilal dengan pelbagai pendekatan. Ibn Manzûr dalam Lisân al-Arab menguraikan asal-usul dan makna kata "hilal" secara panjang lebar. Menurut dia, yang dimaksud "hilal" adalah bulan sabit pada hari pertama dan kedua bulan Kamariah atau dua malam akhir bulan Kamariah. Pendapat ini didasarkan dari Abî Haitham. ${ }^{12}$ Selanjutnya al-Qâmûs al-Muhît $\underline{t}$ menjelaskan bahwa yang dimaksud "hilal" adalah bulan sabit (2-3 malam dari awal bulan/ 7-2 malam dari akhir bulan). ${ }^{13}$ Pendapat ini kemudian diikuti Kamus Al-Munawwir. Namun demikian, Kamus al-Munawir juga menjelaskan pelbagai makna dari kata "hilal". Menurut dia, kata "hilal" memiliki dua belas makna. Makna-makna dimaksud adalah: (1) bulan sabit, (2) cap, selar pada unta, (3) bulan yang terlihat pada awal bulan, (4) unta yang kurus, (5) curah hujan, (6) kulit kelongsong ular, (7) permulaan hujan, (8) debu, (9) air sedikit, (10) ular jantan, (11) warna putih pada pangkal kuku, dan (12) anak muda yang bagus. ${ }^{14}$

${ }^{12}$ Lihat Ibn Manzûr, Lisan al-'Arab, juz XIII, (Misir: al-Mu’assasah al-Misriyyah, t.th.), h. 227-230.

13 Al-Fayruzzabadi, Al-Qâmûs al-Muhît, (Bayrût: Dâr al-Fikr, 1415/1995), h. 966.

${ }^{14}$ Ahmad Warson, Kamus al-Munawir, h. 1616. Baca pula Harun Nasution, dkk., Ensiklopedi Islam Indonesia, cet. I, (Jakarta: Djambatan, 1992), h. 319.
Kamus Arabic-English Dictionary, karya Hans Wehr, menjelaskan kata "hilal", bentuk pluralnya ahillah atau ahâlil, bisa berarti newmoons (bulan muda) atau cresent (sabit). ${ }^{15}$ Definisi ini juga berkembang pada karya-karya berbahasa Inggris, seperti Muhammad Baqir Behbudi dalam karyanya, The Quran A New Interpretation, terjemahan Collin Turner ${ }^{16}$ dan A. Yusuf Ali dalam karyanya The Holy Qur'an Text, Translation and Commentary. ${ }^{17}$

Dalam keterangannya mengenai arti kata dan pengertian hilal yang terkandung dalam Q.s. al-Baqarah [2] ayat 189, Kitab Tafsir Departemen Agama antara lain mengatakan bahwa para ahli tafsir cenderung melihat pada aspek gunanya atau hikmahnya bukan sebab hakikatnya tentang keadaan bulan secara ilmiah. ${ }^{18}$ Selanjutnya Al-Qur'an dan Tafsirnya Departemen Agama menyebutkan:

\begin{abstract}
Ini bukan berarti bahwa ajaran Al-Qur'an yang dibawa oleh Muhammad saw. mengabaikan kepentingan ilmu, malah bukan sedikit ayat Al-Qur'an dan Hadis yang menyuruh untuk memperkembangkan ilmu pengetahuan duniawiyah sebanyak mungkin, tetapi tidak memberikan perincian, hanya memberikan petunjuk untuk mencari dan membahas, sesuai dengan kemampuan, keadaan dan perkembangan zaman, sebagai ummat yang diamanatkan Allah untuk menjadi khalifah di bumi ini. ${ }^{19}$
\end{abstract}

Karya orientalis B. Lewis, V. L. Menage, Ch. Pellat, dan J. Schacht, The Encyclopaedia of Islam menjelaskan arti kata dan pengertian kata "hilal" sama seperti yang digunakan dalam literatur-literatur berbahasa Inggris yaitu bulan muda (newmoons) atau sabit (cresent). ${ }^{20}$ Buku lain yang barangkali paling komprehensif dalam menguraikan kata hilal adalah karya 'Adnân 'Abd alMun'im Qâdî, Al-Ahillah: Nażah Shumûliyah wa Dirâsah Falakiyyah. Buku ini mengulas persoalan hilal dari perspektif syariah dan sains kaitannya dalam

${ }^{15}$ Hans Wehr, Arabic-English Dictionary, h. 1208. Lihat John M. Echols dan Hassan Shadily, Kamus Inggris Indonesia, cet. XIV, (Jakarta: PT Gramedia, 1986), h. 155 dan 385. Baca juga AS Hornby, Oxford Advanced Learner's Dictionary of Current English, cet. XXIII, (New York: Oxford University Press, 1986), h. 548. Bandingkan pula Lois Ma'luf, Al-Munjid, h. 38.

${ }^{16}$ Baca Muhammad Baqir Behbudi, The Quran A New Interpretation, terjemahan Collin Turner, cet. I, (London: Curzon press, 1997), h. 16.

${ }^{17}$ A. Yusuf Ali, The Holy Qur'an Text, Translation and Commentary, (Riyad: Amana Corp, 1403 H), h. 75.

${ }^{18}$ Depag RI, Al-Qur'an dan Tafsirnya, jilid I, cet. I, (Jakarta: Yayasan Penyelenggaraan Penterjemah/Pentafsiran Al-Qur'an, 1975), h. 339-340.

${ }^{19}$ Depag RI, Al-Qur'an dan Tafsirnya, jilid I, h. 339-340.

${ }^{20}$ Dalam sejarah kesenian Islam gambar hilal telah digunakan dalam pelbagai aspek, seperti mata uang, piala, motif-motif ornamen, dan bendera. Uraian selengkapnya lihat B. Lewis, dkk., The Encyclopaedia of Islam, vol. III, (Leiden: E.J. Brill, 1971), h. 379-388. 
penentuan awal bulan Kamariah. ${ }^{21}$

Sementara itu para ilmuwan berupaya merumuskan hilal melalui rasionalisasi dan interpretasi Kitab Suci hingga observasi dan eksperimentasi yang akhirnya menghasilkan dua pendekatan tentang hilal, yaitu teoretis dan empiris. Pada zaman keemasan Islam, pendekatan teoretis dipelopori oleh Nasîr al-Dîn alTûsî, ${ }^{22}$ sedangkan pendekatan empiris dipelopori oleh al-Bîrûnî. ${ }^{23}$ Di era modern, pendekatan teoretis dipelopori oleh Bruin, sedangkan pendekatan empiris dipelopori oleh Maunder. Saat ini rekor dunia hilal termuda yang terlihat dengan teropong adalah hilal awal Ramadan 1416 H (21 Januari 1991) dengan umur bulan 12 jam 07 menit yang terlihat oleh Jim Stamm di Tuscon, Arizona Amerika Serikat. ${ }^{24}$ Selama ini, parameter visibilitas hilal sangat dipengaruhi oleh limit Danjon dan Mohammad Ilyas. ${ }^{25}$

Dalam kasus di Indonesia, pendekatan teoretis dipelopori oleh Muhammadiyah dengan mengusung teori wujûd al-hilâl untuk menentukan awal bulan Kamariah, sedangkan pendekatan empiris digunakan oleh Nahdlatul Ulama (NU) dengan menjadikan visibilitas hilal sebagai panduan dalam melakukan observasi. Bagi NU, sebagaimana dinyatakan Ghazali Masruri, hilal harus tampak dan jelas. ${ }^{26}$ Perbedaan pendekatan inilah yang menjadikan salah satu sumber permasalahan dalam menentukan awal bulan Kamariah di Indonesia.

Permasalahan kedua adalah penggunaan hisab dan rukyat dalam menentukan awal bulan Kamariah. Hingga kini perdebatan hisab-rukyat tidak kunjung

21 Selengkapnya baca 'Adnân 'Abd al-Mun'im Qâdî̀, Al-Ahillah Nażrah Shumûliyah wa Dirâsah Falakiyyah, (al-Qâhirah: al-Misriyyah, 1426/2005).

22 Lebih lanjut baca M.M. Syarif (ed.), A History of Muslim Philosophy, vol. 1, (Wiesbaden: Otto Harrassowitz, 1963), h. 576.

${ }^{23}$ Baca Abû Rayhân Muhammad ibn Aḥmad al-Bîrûnî, AlQânûn al-Masî̀dî, di-tahqqîq oleh 'Abd al-Karîm Sami al-Jundî, cet. I, (Bayrût: Dâr al-Kutub al-'Ilmiyyah, 1422/2002). Baca juga 'Abd alAmîr Mu'min, Qâmûs Dâr al-'Ilm al-Falakî, cet. I, (Bayrût: Dâr al'Ilm li al-Malâyîn, 2006). Perhatikan pula Ibrâhîm Hilmî al-Gharrî, Al-Mawsûah al-Falakiyah, cet. I, (Bayrût: Dâr al-Sharq al-'Arabî, 1429/2008).

${ }^{24}$ Temuan Jim Stamm ini dimuat dalam http://www.icoproject. org. dan juga disampaikan dalam Muktamar Falak kedua di Abu Dhabi. Uraian selengkapnya baca Conference Book "The Second Emirates Astronomical Conference: Role of Astronomy in the Islamic Society Applications in Islam, Education and Environment", (Abu Dhabi: National Center for Documentation \& Research, 2010).

${ }^{25}$ Mohammad Ilyas, "The Danjon Limit of Lunar Visibility: A ReExamination", dimuat The Journal of the Royal Astronomical Society of Canada, 77/1983, h. 214-219.

${ }^{26}$ Selengkapnya baca "Redefinisi Hilal Sebuah Keniscayaan", dimuat dalam Majalah Islami Bulanan Khalifah', edisi 3 Tahun I/ 17 Agustus - 13 September 2008/14 Sya'ban - 12 Ramadhan 1429, h. 7. selesai masing-masing pihak merasa lebih sesuai dengan pesan nas. Di Indonesia, perbedaan ini sangat tampak antara Muhammadiyah dan NU. Bagi NU, kedudukan hisab hanya sebagai pembantu dalam pelaksanaan ru'yah al-hilâl di lapangan. Oleh karena itu, meski sudah melakukan prediksi, mereka tidak berani memastikan awal bulan Ramadan, Syawal, dan Zulhijah dengan hisab, tetapi tetap menunggu hasil observasi di lapangan. Seperti telah diketahui NU mengulang-ulang Hadis Nabi Saw., "Śmûu li ru'yatih", sebagai justifikasi. Mereka mengakui bahwa kata hilal (newmoon) yang terdapat dalam Q.s. al-Baqarah [2] ayat 189 bersifat general. Akan tetapi kaitannya dengan awal Ramadan dan Syawal, Hadis-hadis rukyat dianggap paling tegas dan jelas sebagai landasan ber-istinbat. ${ }^{27}$ Tegasnya, rukyat merupakan landasan utama bagi NU dalam menetapkan awal dan akhir Ramadan. ${ }^{28}$

Sikap NU juga sama dengan yang berkembang di negara Saudi Arabia, ${ }^{29}$ Syiria, ${ }^{30}$ Maroko, ${ }^{31}$ dan Bahrain. ${ }^{32}$ Shaykh al-Islâm, Ibn Taymiyyah, sebagaimana dikutip Nurcholish Madjid juga mendukung penggunaan rukyat. Karena menurut dia, ilmu hisab meskipun secara logika kebenarannya dapat dipercaya dan mendekati kebenaran dibandingkan ilmu-ilmu yang lain. Namun, ia tetap memiliki keterbatasan dalam menangkap pesan ilahi, khususnya untuk menentukan awal bulan Kamariah (awal Ramadan dan Syawal). Ibn Taymiyyah menegaskan bahwa nalar deduksi tidak akan membawa kebahagiaan manusia. ${ }^{33}$ Argumentasi Ibn Taymiyyah ini dapat dimaklumi karena pada saat itu orang sudah melupakan hukum-hukum agama dan mendewakan ilmu-ilmu yang positivistik. Jadi, posisinya bukan menjustifikasi benar atau salah

\footnotetext{
${ }^{27}$ Wawancara dengan Muhyiddin pada 13 November 2000 di Yogyakarta.

${ }^{28}$ Selengkapnya baca PB NU, Pedoman Hisab dan Rukyat, (Jakarta: Lajnah Falakiyah PB NU, 1994), h. 2.

${ }^{29}$ Menurut Zaki al-Mostafa salah seorang yang bertanggung jawab terhadap kalender Ummul Qurẩ menyatakan bahwa sejak $1423 \mathrm{H}$ Saudi Arabia dalam menentukan awal bulan kamariah menggunakan teori wiladah al-hilâl artinya ijtimak terjadi sebelum ghurûb dan matahari terbenam terlebih dahulu dibandingkan bulan. Teori ini hampir sama dengan teori wujûd al-hilâl Muhammadiyah.

${ }^{30}$ Wawancara dengan Basil Tamim pada tanggal 27 Ramadan 1425 H/ 10 November 2004 M di Universitas Madinah.

31 Dilaporkan oleh Buitelaar dalam disertasinya yang berjudul "Fasting and Feasting in Morocco An Ethnographic Study of The Month of Ramadan" (1991) sebagaimana dikutip oleh André Moller.

${ }^{32}$ Selengkapnya baca harian al-Ittihad, 13 Nopember 2004, h. 1.

${ }^{33}$ Baca Nurcholish Madjid. "Ibn Taymiyya on Kalam and falsafa (A Problem of Reason and Revelation in Islam)", (Chicago: A Dissertation Submitted to The Faculty of Division on The Humanities in Candidacy for The Degree of Doctor of Philosophy, 1984), h. 235-236. Baca juga Ibn Taymiyyah, Al-Radd 'ala al-Mantiqiyyinn, (Bombay: Sharaf al-Din al-Kutub wa Awlâdah, 1368/1949), h. 264-265.
} 
melainkan ingin mengembalikan ilmu ke pangkalnya (Alquran dan Sunah). Begitu pula, Syeikh 'Abd Allâh ibn Baz, Ketua Lajnah Daimah untuk Riset Ilmiah dan Fatwa Saudi Arabia, berpendapat bahwa untuk memulai awal Ramadan dan Syawal hanya dengan rukyat atau istikmal. Hal ini didasarkan Hadis Sahih, "Berpuasalah karena melihatnya (hilal), dan berbukalah karena melihatnya (hilal), namun jika tertutup awan maka sempurnakanlah bulan Syakban tiga puluh hari. Selanjutnya, 'Abd Allâh ibn Baz menganggap penggunaan ilmu falak (hisab) dalam menetapkan awal Ramadan dan Syawal termasuk bidah yang tidak ada kebaikan di dalamnya, juga tidak mempunyai landasan dalam syariah. Hal itu sesuai penjelasannya:

Di sini Rasulullah Saw. menetapkan puasa dengan melihat hilal Ramadan dan berhari raya dengan melihat hilal Syawal, dan beliau tidak berpedoman dengan hisab perbintangan dan peredaran planet. Demikianlah yang dilakukan di masa Nabi Saw., al-Khulafầ al-Râshidîn, imam yang empat, dan tiga abad yang dikatakan Rasulullah sebagai zaman terbaik.

Menetapkan bulan Kamariyah dengan ilmu falak dalam memulai ibadah dan mengakhirinya tanpa rukyah termasuk bidah yang tidak ada kebaikan di dalamnya, juga tidak mempunyai landasan dalam syariat. Oleh karena itu, Kerajaan Saudi Arabia berpegang kepada apa yang telah dicontohkan Rasulullah Saw. dan para salaf al-sâlih dalam hal penetapan puasa dan hari raya serta waktu-waktu haji yaitu melihat hilal. ${ }^{34}$

'Abd Allâh ibn Baz berpendapat tersebut telah disetujui oleh Dewan Ulama Senior di Kerajaan Saudi Arabia. ${ }^{35}$ Akibatnya, hampir mayoritas ulama di Saudi Arabia berpendapat bahwa hisab adalah bidah. ${ }^{36}$ Namun dalam perkembangannya, sejak tahun 1430/2009 di Saudi Arabia dalam menentukan awal Ramadan, Syawal, dan Zulhijah tidak semata-mata menggunakan rukyat tetapi juga memerhatikan hasil hisab dengan melibatkan para astronom di Majelis al-Qadầ al-A'lâ. ${ }^{37}$ Perubahan paradigma ini berdasarkan masukan dan kritik dari pelbagai pihak, seperti hasil penelitian Ayman Kordi,

${ }^{34}$ Baca 'Abd Allâh ibn Baz, Kumpulan Fatwa Puasa, terjemahan Anshari Taslim dan E. Rukmana, (Jakarta: Khairul Bayan, 2003), h. 15.

35 'Abd Allâh ibn Baz, Kumpulan Fatwa Puasa, h. 15.

${ }^{36}$ Kenyataan ini penulis temukan saat melakukan penelitian di Saudi Arabia. Buku-buku yang membicarakan persoalan puasa menyebutkan bahwa untuk memulai dan mengakhiri puasa dengan rukyat, sedangkan hisab hukumnya bidah. Selengkapnya baca Muhammad ibn $\underline{\text { Sallih }}$ al-Munjid, Mas'alah fi al-Siyâmî, (Riyâd: Markaz Khidmah al-Mutabarayn bi al-Kitâb, 1425 H), h. 4.

${ }^{37}$ Baca harian Asharq al-Awsat, Selasa, Jumadil awal 1430/ 28 April 2009, h. 1. Baca juga Zaki ibn 'Abd al-Rahmân al-Mustafâ, A $\underline{\text { hwâl al- }}$ Ahillah li Am 1431 H, cet. I, (Riyâd: KACST, 1431/2010). Perhatikan pula Sâlih Muhammad al-Sa'b, al-Shuhûr al-Qamariyyah wa Tahdîd Bidâyatuhâ, cet. II, (Riyâd: KACST, 2010). salah seorang ahli astronomi Islam dari King Saud University, menyimpulkan bahwa selama 40 tahun hasil ruyah al-hilâlyang diumumkan pemerintah Saudi Arabia $87 \%$ salah dan tidak dapat dipertanggungjawabkan secara keilmuan. ${ }^{38}$ Sementara itu Organisasi Islam di Luar Negeri yang mendukung penggunaan rukyat untuk menentukan awal Ramadan dan Syawal, di antaranya yaitu Hilal Sighting Committee of North America (Komite Penyatuan Hilal Amerika Utara) dan Hilal Committee of Metropolitan Toronto. Baginya hisab tidak dapat digunakan sebagai cara yang sahih untuk menentukan Kalender Hijriah. Hasil hisab hanya dapat digunakan sebagai petunjuk bila tidak mungkin dapat melihat hilal. Dalil yang digunakan Q.s. al-Baqarah [2] ayat 185 dan Hadis-hadis rukyat. Kesemuanya diinterpretasikan melihat hilal secara visual dan masuk dalam prosesi ibadah yang tidak boleh digantikan dengan hisab. ${ }^{39}$

Pada 11-13 Februari 2012 dilaksanakan muktamar "Ithbât al-Shuhûr al-Qamariyyah bayn 'Ulamâ' al-

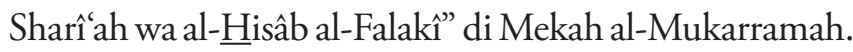
Muktamar ini diselenggarakan oleh Râbitah 'Alam alIslâmî. Hasil muktamar ini merekomendasikan terbentuknya komite yang terdiri atas pakar astronomi dan ulama untuk menyatukan awal bulan hijriah di Negaranegara muslim. Komite ini menetapkan Mekah sebagai pusat observasi dan akan membuat kalender hijriah yang berlaku bagi seluruh negara muslim. Muktamar ini menekankan pentingnya observasi dalam menentukan permulaan Ramadan, Syawal, dan Zulhijah. Para peserta menyatakan Islam tidak keberatan memanfaatkan teknologi modern untuk melakukan observasi dalam penentuan awal bulan hijriah. Para peserta sepakat pula, mereka yang tinggal di negara yang Muslim menjadi minoritas mesti memulai dan mengakhiri puasa Ramadan jika bulan baru teramati di wilayah mana pun di Negara tersebut. Bila tidak dapat mengamati bulan baru karena pelbagai alasan, mereka dapat mengikuti Negara Muslim terdekat atau komunitas muslim terdekat. ${ }^{40}$

Sementara itu, Muhammadiyah mempertautkan antara dimensi ideal wahyu dan peradaban manusia. Karena itu, dalam menetapkan awal Ramadan dan Syawal Muhammadiyah tidak semata-mata dengan rukyat tapi juga menggunakan hisab. ${ }^{41}$ Bagi Muhammadiyah

${ }^{38}$ Selengkapnya baca Bangla Post, London 18 September 2008. Baca juga Susiknan Azhari, "Kebersamaan Idul Fitri 1429", dimuat dalam harian Republika, Jum'at, 26 September 2008, h. 6. Lihat juga dialog Mohammad Odeh di TV al-Jazeera, http://www.icoproject.org. diakses 25 Oktober 2011, pukul 7.30 WIB.

39 Tono Saksono. Mengkompromikan Rukyat \& Hisab, cet 1, (Jakarta: Amythas Publicita, 2007), h. 140.

${ }^{40}$ Email pribadi dari Mohammad Odeh 15 Februari 2012.

${ }^{41}$ Baca Djarnawi Hadikusuma. "Mengapa Muhammadiyah 
yang mengembangkan nalar rasional-ilmiah, rukyat tidak semata-mata dipahami secara literal-parsial, tetapi didialogkan dengan ayat-ayat terkait, seperti Q.s. alBaqarah [2] ayat 185, Q.s. Yûnus [10] ayat 5, Q.s. Yâsîn [36] ayat 39-40, dan Q.s. al-Rahmân [55] ayat 5 sehingga metodologi yang dikembangkan Muhammadiyah dalam menetapkan awal bulan Kamariah sangat elastisproduktif. ${ }^{42}$ Penggunaan hisab tidak hanya terfokus pada bulan Ramadan dan Syawal tetapi digunakan dalam sebuah sistem kalender Islam, yaitu sejak Muharam hingga Zulhijah. ${ }^{43}$ Kebolehan penggunaan hisab ini diperkuat dengan data historis bahwa penentuan awal bulan kamariah tidak semata-mata dengan rukyat tapi bisa menggunakan hisab. Asjmuni Abdurrahman dalam uraiannya menyebutkan: ${ }^{44}$

Penentuan awal bulan Ramadan maupun Syawal dengan hisab bukanlah pada masa sekarang saja. Kalau kita membuka kitab Bidayatul Mujtahid susunan Ibn Rushd seorang ulama mazhab Mâlikî (520-595 H/1126$1198 \mathrm{M}$ ), akan kita dapati bahwa penggunaan hisab oleh sebagian ulama sejak masa Sahabat atau Tabi'în. Dalam kitab ini dinyatakan bahwa penentuan awal bulan kalau dilakukan rukyat tidak terlihat karena mendung, maka dengan melakukan hisab. Hal ini telah dilakukan oleh sebagian ulama salaf, dalam hal ini dipelopori oleh tokoh senior tabiîn yang bernama Matarif ibn al-Shahr. Oleh sebagain ulama Shâfiiyyah dinyatakan bahwa ahli hisab dan yang memercayai (kebenaran perhitungannya) wajib melakukan puasa berdasarkan pada hisabnya.

Kutipan di atas sejalan dengan uraian yang terdapat pada Ensiklopedi Islam yang menyebutkan:

Di antara ulama yang tertarik untuk menentukan awal atau akhir bulan Ramadan dengan hisab itu adalah

Memakai Hisab?", dimuat dalam Suara Muhammadiyah, No. I, Th. Ke-53, Dzulhijah 1392/ Januari 1973. Baca juga Susiknan Azhari. "Penentuan Awal Ramadan dan Syawal Model Muhammadiyah", dimuat dalam Suara Muhammadiyah, No. 23 Th. Ke-85, h. 37 - 38. Patut diketahui dalam Keputusan Tarjih yang telah menjadi tuntunan, pada kitab puasa dalam judul Kaifiyah Shiyam, ada 4 cara yang dapat ditempuh oleh Muhammadiyah dalam menentukan awal dan akhir puasa Ramadan, yaitu (1) Ru’yah al-hilâl, (2) Mendengarkan persaksian orang yang adil, (3) Istikmal, dan (4) Hisab. Penjelasan selengkapnya baca Asjmuni Abdurrahman. "Menentukan Awal Bulan Ramadan, dan Syawal Berdasar Hisab Termasuk Bid'ah ?", dimuat dalam majalah Suara Muhammadiyah, No. 1, Tahun ke-89, 1 - 15 Januari 2004 M/23 Zulqa'dah 1424 H, h. 24-25.

42 Selengkapnya baca Majelis Tarjih dan Tajdid Pimpinan Pusat Muhammadiyah. Pedoman Hisab Muhammadiyah, cet. II, (Yogyakarta: Majelis Tarjih dan Tajdid PP. Muhammadiyah, 1430/2009), h. 73-79.

${ }^{43}$ Lihat Kalender Muhammadiyah (perhatikan lampiran).

${ }^{44}$ Lihat Asjmuni Abdurrahman. "Penentuan Awal Bulan Ramadlan dan Satu Syawal”, dimuat dalam majalah Suara Muhammadiyah, No. 17/Th. Ke-83 (1-15 September 1998), h. 31. Baca juga Ibn Rusyd. Bidayatu al-Mujtahid wa Nihayatu al Muqtasid, (Bayrût: Dâr al-Fikr, t.t), I: 208. Bandingkan pula Khalid Shaukat. "A Suggested Global Islamic Calendar", h. 3, dimuat dalam http://www.moonsighting.com, diakses 23 Oktober 2011, pukul 11.57 WIB.
Ibnu Banna, Ibn Suraij, al-Qaffal, Kadi Abu Taib, Ibnu Qutaibah, Ibnu Muqatil ar-Razi, Ibnu Daqiq al-Id, dan Subki. Sementara itu ulama abad ke-20 yang cenderung mempergunakan hisab dalam menentukan awal atau akhir bulan Ramadan ialah Muhammad Rasyid Rida dan Tantawi Jauhari. ${ }^{45}$

Pola pemikiran Muhammadiyah di atas sama dengan yang berkembang di Pakistan, ${ }^{46}$ Tajikistan, ${ }^{47}$ Turki, dan Mesir. ${ }^{48}$ Yûsuf al-Qaradawî, salah seorang ulama dan pemikir Islam abad ini, juga menyerukan penggunaan hisab dalam menetapkan awal dan akhir Ramadan, demi memperkecil perbedaan yang biasa terjadi saat memasuki awal puasa dan Idul Fitri. ${ }^{49}$ Bagi dia, Hadishadis tentang rukyat harus dibaca secara situasionalkontekstual. Pada saat itu, perintah penggunaan rukyat dalam menetapkan awal Ramadan dan Syawal sangat relevan dengan kondisi masyarakat setempat. Namun kini peradaban manusia sudah berkembang pesat dan didukung teknologi yang canggih, penggunaan hisab merupakan solusi yang terbaik. ${ }^{50}$

Al-Subki dalam Fatâwâ-nya, sebagaimana dikutip Yûsuf al-Qaradawî, menyebutkan hisab adalah qath'i, sedangkan rukyat adalah zannî. ${ }^{51}$ Karena itu, bagi Muhammad Syakir, penggunaan hisab di era modern merupakan sebuah keniscayaan. Hal itu mengingat bahwa hukum tentang penetapan masuknya bulan dengan rukyat, dikaitkan dengan suatu sebab (illah) yang dijelaskan oleh Sunah itu sendiri. Padahal, "sebab" tersebut di masa sekarang, telah tiada lagi, dan seperti telah ditetapkan, setiap hukum berjalan bersama 'illah-nya,

${ }^{45}$ Lihat A. Hafidz Dasuki, dkk, Ensiklopedi Islam, cet. I, Jakarta: Ichtiar Van Hoeve, 1994, h. 119. Baca juga Tantawî al-Jawharî, AlJawâhir fî Tafsîr al-Qur'ân al-Karîm, juz VI, (Bayrût: Dâr al-Fikr, t.th), h. 19. Perhatikan pula Muhammad Rashîd Ridâ, Tafî̀r al-Manâr, juz II, (Bayrût: Dâr al-Fikr, t.th), h. 301-304. Bandingkan pula dengan Muhammad Imârah, Al-A'mal al-Kâmilah li al-Imâm Syeikh Muhammad 'Abduh, juz II, cet. I (al-Qâhirah: Dâr al-Shurûq, 1993), h. 512 - 513.

46 Wawancara dengan Fadzlurrahman pada tanggal 27 Ramadan 1425 H/ 10 Nopember 2004 di Universitas Madinah. Baca juga Abdullah bin Nuh, "Hanya Ada satu Djalan Bagi Umat Islam seluruh Dunia Untuk Bersatu Dalam Memulai dan Mengachiri Ramadan dan Menentukan Hari Raja Idul Fitri dan Idul Adha", dalam Al-Jamia'ah, 5-6/Sept-Nov/1967.

${ }^{47}$ Wawancara dengan Abdul Hamy pada 27 Ramadan 1425 H/ 10 Nopember 2004 di Universitas Madinah.

${ }_{48}$ Penuturan Abdul Aziz Bakrie, Guru Besar Falak Universitas Al-Azhar Kairo-Mesir bahwa Mesir dalam menentukan awal bulan Kamariah memerhatikan aspek astronomi dan falak shar'i serta posisi hilal saat terbenam matahari setelah terjadi ijtimak. Wawancara dilakukan pada 1 Desember 2004 di ruang Jurusan Falak Universitas Al-Azhar, Kairo, Mesir.

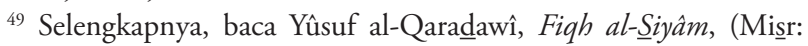
Dâr al-Wâfî, t.th), h. 48 dan Kayfa Nata'ammal ma'a al-Sunnah alNabawiyyah, cet. II (al-Qâhirah: Dâr al-Shurûq, 2002), h. 165.

${ }^{50}$ Selengkapnya, baca Yûsuf al-Qaradawî, Fiqh al-Siyâm, h. 165.

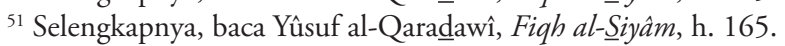


dalam keberadaannya ataupun ketiadaannya. ${ }^{52}$ Beberapa fukaha modern terkemuka, seperti Syeikh Mustafâ Aḥmad al-Zarqâ dan 'Abbâs al-Jirârî juga menyerukan umat Islam untuk menggunakan hisab. ${ }^{53}$ Organisasi Islam di luar Indonesia yang mendukung penggunaan hisab, yaitu Islamic Society North America (ISNA). Pada awalnya, ISNA dalam penentuan awal Ramadan, Syawal, dan Zulhijah menggunakan rukyat. Namun setelah melakukan penelitian panjang dengan Committee for Crescent Observation (CFCO) sejak tahun 1994 hingga 2006 (12 tahun) akhirnya ISNA menyimpulkan bahwa cara rukyat tidak mungkin dilakukan untuk menentukan awal Ramadan dan Syawal. ${ }^{54}$ Begitu pula dalam konferensi yang bertajuk "Jadaliyah al-Alâqah bayn alFiqh wa al-Falakî" yang diselenggarakan di Lebanon pada 10-12 Rabiul Awal 1431 H/ 25-26 Februari 2010 yang menghadirkan narasumber Yusuf Marwah (Kanada), Mohammad Odeh (ICOP), Sâlih al-Ujayrî (Kuwait), Khâlid al-Zaaq (Saudi Arabia), Muhammad al-Ushayrî (Syria), dan Musallam Syalthout (Mesir) menyepakati penggunaan hisab untuk menentukan awal bulan Kamariah dalam rangka mewujudkan kalender Islam. ${ }^{55}$ Selanjutnya, karya terbaru yang mengulas secara komprehensif tentang perdebatan hisab dan rukyat ditulis oleh Zulfiqar Ali Shah (2009) dengan judul "The Astronomical Calculations and Ramadan A Fiqhi Discourse". Setelah dijelaskan secara panjang lebar masing-masing argumentasi para pendukung hisab

52 "Sebab" ('illah) yang dimaksud adalah kemampuan umat menguasai ilmu falak (hisab). Menurut dia, tidaklah masuk akal Rasulullah Saw. memerintahkan umat untuk menggunakan hisab pada suatu masa ketika (kebanyakan) mereka masih ummî, tidak pandai menulis, dan tidak pula menghitung. Justru beliau menetapkan suatu cara yang cocok bagi mereka, ditinjau dari segi ruang dan waktu yakni cara rukyat yang dapat dipraktikkan oleh kebanyakan orang di masa beliau. Akan tetapi, apabila telah ditemukan cara yang lebih cermat, lebih tepat dan lebih jauh dari kesalahan tidak ada satupun dalil yang melarang penggunaan hisab. Penjelasan selengkapnya baca Ahmad Muhammad Syakir, Menentukan Hari Raya dan Awal Puasa, terjemahan K.H. Mahrous Ali, cet. I (Surabaya: Pustaka Progresif, 1993), h. 18-19.

${ }^{53}$ Mustafâ Ahmad al-Zarqâ mengatakan, "...Saya yakin bahwa ulama salaf kita yang awal, yang tidak menerima penggunaan hisab karena alasan-alasan tertentu, seandainya mereka hidup sekarang pada zaman ini dan menyaksikan perkembangan dan kemajuan spektakuler yang dicapai oleh ilmu hisab, mereka akan mengubah pendapat mereka karena mereka telah dianugerahi oleh Allah keluasan cakrawala pemikiran mengenai tujuan syariah, yang tidak diperoleh oleh pengikut mereka yang kemudian. Selengkapnya baca Mustafâ Ahmad al-Zarqâ,

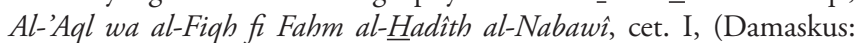
Dâr al-Qalam, 2004), h. 72-74.

${ }_{54}^{4}$ Masih banyak lagi organisasi Islam maupun perorangan baik di Amerika Utara maupun Eropa yang mendukung penggunaan hisab. Lihat Tono Saksono, Mengkompromikan Ru'yat \& Hisab, h. 131-139.

55 Selengkapnya baca harian Al-Akhbar, Senin 15 Adzar 2010/15 Maret 2010. dan rukyat, Zulfiqar berkesimpulan bahwa untuk saat ini yang lebih relevan untuk menentukan awal bulan Kamariah adalah hisab. ${ }^{56}$

\section{Kalender Islam Berbasis Riset: Solusi Menuju Unifikasi}

Seperti diuraikan pada awal tulisan ini bahwa keberlakuan kalender Islam masih bersifat lokal sehingga sering menimbulkan perbedaan dalam menentukan Idul Adha antara Saudi Arabia dengan negara-negara Islam lainnya. ${ }^{57}$ Mohammad Ilyas, salah seorang astronom Muslim dari Malaysia, menggagas perlunya kalender Islam internasional dengan memperkenalkan konsep "garis qamari antarbangsa" atau biasa diistilahkan International Lunar Date Line (ILDL). ${ }^{58}$ Konsep ini mula pertama dilontarkan pada tahun 1978. Bagi Ilyas, penyatuan bukan berarti berhari raya di waktu yang sama di seluruh penjuru dunia, karena jelas tidak mungkin. Menurut dia, belum adanya kalender Islam internasional sebagai bukti ketertinggalan umat Islam di bidang sains dan teknologi. Itulah sebabnya diperlukan kerja keras dan mimpi besar untuk mewujudkannya melalui peningkatan pemahaman masyarakat tentang kalender Islam internasional.

Berdasarkan kenyataan di atas, Ilyas berusaha mewujudkan impiannya melalui International Islamic Calendar Programme (IICP) yang bermarkas di Universiti Sains Malaysia. Hasil riset-riset ini kemudian disebarkan ke negara-negara Islam yang tergabung dalam Organisasi Konferensi Islam (OKI) untuk didialogkan melalui pertemuan-pertemuan regional dan internasional, seperti Konferensi Penyatuan Awal Bulan Kamariah di IstanbulTurki pada tanggal 26-29Zulhijah 1398/27-29 November 1978, Seminar Penanggalan Islam Antarbangsa pada 8-10 Juni 1988 di Malaysia, ${ }^{59}$ dan Konferensi Kalender Islam Internasional pada 29 Rabiul Awal-1 Rabiul Akhir 1412/ 8-10 Oktober 1991 di Penang Malaysia. ${ }^{60}$

${ }^{56}$ Lihat, Zulfiqar Ali Shah, The Astronomical Calculations and Ramadan A Fighi Discourse, cet. I, (USA: The International Institute of Islamic Institute of Islamic Thought, 1430/2009). Baca juga Syamsul Anwar, Interkoneksi Studi Hadis dan Astronomi, cet. I, (Yogyakarta: Suara Muhammadiyah, 2011), h. 181-205.

${ }^{57}$ Mashallah Ali Ahyaie, "Contradictions in Taghwim Recent Past and Present", makalah dipresentasikan pada The 20 th International Congress of History of Science, Belgia, 20-26 Juli 1997, h. 6.

58 Lihat Mohammad Ilyas, Islamic Astronomy and Science Development Glorious Past Challenging Future, cet. I, (Selangor Darul Ehsan Malaysia: Pelanduk Publication, 1996), h. 112-119.

${ }^{59}$ Hasil seminar tersebut dapat dibaca pada Panji Masyarakat, no. 582, 7-16 Zulhijjah 1408, 21-30 Juli 1988, h 74-76.

${ }^{60}$ Musa Mohamad (ed.), Towards Implementation of A Unified Islamic Calendar, cet. I, Penang-Malaysia: International Islamic Calendar Programme, 1998). 
Gagasan Ilyas memberi inspirasi bagi para pemikir tentang kalender Islam internasional, seperti Nidhal Guessoum dan Mohammad Odeh. Pada Muktamar Falak kedua 16-18 Jumadil Akhir 1431/30 Mei-1 Juni 2010 di Abu Dhabi, pemikiran tentang kalender Islam internasional mengerucut pada dua model, yaitu (1) Kalender Zonal dan (2) Kalender Terpadu. Kalender Zonal dipelopori Nidhal Guessoum dan Mohammad Odeh, sedangkan kalender terpadu dipeloporiJamaluddin Abder Razik, Khalid Shaukat, dan Muhibullah Durrani ${ }^{61}$

Selanjutnya sebagaimana dikatakan M. Amin Abdullah bahwa pendekatan kajian Islam monodisiplin tidak lagi memadai untuk menjawab tantangan zaman yang serba berubah. ${ }^{62}$ Begitu pula upaya penyatuan kalender Islam tidak hanya berkutat pada persoalan kriteria yang harus diterima. Tetapi harus mengkaji persoalan-persoalan fundamental terkait dengan sistem kalender Islam melalui pendekatan interdisipliner. Selama ini upaya penyatuan kalender Islam di Indonesia lebih bersifat pragmatis belum memasuki wilayah substantif-filosofis. Akibatnya, muncul pro-kontra di kalangan masyarakat dalam merespons isu tersebut.

Konteks di Indonesia ditemukan dua mainstream besar dalam merespons penyatuan kalender Islam. Kelompok pertama optimis. Mereka berpendapat penyatuan sebuah keniscayaan dalam rangka mewujudkan kalender Islam. Belum terwujudnya kalender Islam yang dapat diterima semua pihak bukan berarti tidak mungkin diupayakan. Kehadiran kalender Islam yang mapan merupakan suatu "tuntutan peradaban" (civilizational imperative). ${ }^{63}$ Sementara itu, kelompok kedua pesimis. Kelompok ini berpandangan bahwa hisab dan rukyat merupakan dua entitas yang tidak dapat dipertemukan. Keduanya memiliki epistemologi dan metodologi yang berbeda. Karena itu, biarkan keduanya berjalan sesuai epistemologi dan metodologi yang diyakini. ${ }^{64}$ Menurut dia, sampai kiamat perbedaan

${ }^{61}$ Uraian selengkapnya baca Conference Book "The Second Emirates Astronomical Conference: Role of Astronomy in the Islamic Society Applications in Islam, Education and Environment, (Abu Dhabi: National Center for Documentation \& Research, 2010). Baca juga Nidhal Guessoum dan Mohammad Odeh, Applications of Astronomical Calculations to Islamic Issues, cet. I, (Abu Dhabi: ICOP, EAS \& CDR, 2007). Bandingkan pula Syamsul Anwar, Hari Raya \& Problematika HisabRukyat, cet. 1, (Yogyakarta: Suara Muhammadiyah, 2008), h. 115-147.

${ }^{62}$ Baca harian Republika, Rabu, 14 Dzulqaidah 1432/12 Oktober 2011, h. 12.

${ }^{63}$ Baca Syamsul Anwar, Hari Raya \& Problematika Hisab-Rukyat, h. 116. Baca juga Al-Ahwani, "The Islamic Lunar Calendar as a Civilizational Imperative", dimuat dalam Ilyas dan Kabeer (ed.). Unified World Islamic Calendar: Sharia, Science and Globalization, (Penang, Malaysia: International Islamic Calendar Programme, 2001), h. 9.

${ }^{64}$ Baca A. Mustafa Bisri, "Begitu Aja Kok Repot". Dimuat dalam antara hisab dan rukyat tidak akan dapat dipertemukan sehingga muncul istilah Lakum Ru'yatukum Waliy $\underline{H}$ isâbî, bagimu rukyatmu dan bagiku hisabku. ${ }^{65}$ Perbedaan keduanya sangat tipis sekali. Kelompok pertama penyatuan sulit dilakukan tetapi mungkin diwujudkan, sedangkan kelompok kedua penyatuan mungkin dilakukan tetapi sulit diwujudkan.

Melihat realitas seperti di atas tampaknya upaya penyatuan kalender Islam tidak boleh dilakukan dengan menegasikan pihak lain. Tetapi harus dilakukan melalui kerja akademik yang terencana dan terarah. Bagi penulis, bukan pada posisi di bawah atau di atas dua derajat kedudukan hilal. Tetapi yang terpenting bagaimana membangun teori berbasis riset yang memadukan aspek syariah dan sains. Oleh karena itu, sudah saatnya dibentuk tim penyatuan kalender Islam dengan melibatkan pelbagai disiplin keilmuan. Dengan kata lain yang mampu menyatukan umat dalam konteks kalender Islam bukan hanya astronomi tetapi ilmu-ilmu lain juga memiliki peluang yang sama. Jika hasilnya wujûd al-hilâl yang lebih aplikatif sesuai tuntutan syariah dan sains serta relevan untuk masa kini, maka marilah diterima dengan lapang dada. Begitu pula jika visibilitas hilal lebih sesuai semua pihak juga harus siap menerima dengan sikap gentleman agreement.

\section{Penutup}

Penyatuan bukan untuk dipaksakan tetapi perlu diupayakan melalui riset yang komprehensif dan dialog yang asertif. Tidak kalah penting kesadaran dan pemahaman umat Islam tentang kalender Islam perlu ditingkatkan. Masing-masing pihak perlu memiliki sifat kenegarawanan dan tidak mementingkan golongan. Hanya dengan mau rendah hati dan menyadari kelemahan masing-masing titik temu dapat diupayakan, Konteks Indonesia penyatuan kalender Islam tidak dapat dipisahkan dengan upaya mendialogkan antara wujûd al-hilâl dan visibilitas hilal. Oleh karena itu, perlu direnungkan pernyataan K.H. Syukri Ghazali sebagai berikut, "Mengharap Badan Hisab dan Rukyat Departemen Agama memperhatikan masyarakat Islam Indonesia. Bila masyarakat dipaksa menganut suatu pendapat sebelum ada titik pertemuan dari pelbagai pendapat, maka usaha untuk mempersatukan pendapat akan mengalami kegagalan". ${ }^{66}[]$

\footnotetext{
harian Jawa Pos, Rebo Kliwon, 15 Maret 2000, p. 7.

${ }^{65}$ Baca harian Republika, Rabu 14 Januari 1998.

${ }^{66}$ Lihat A. Wasit Aulawi, Laporan Musyawarah Nasional Hisab dan Rukyat 1977, (Jakarta: Ditbinbapera, 1977), III: h. 4.
} 


\section{Pustaka Acuan Buku:}

Ali Shah, Zulfiqar, The Astronomical Calculations and Ramadan A Fiqhi Discourse, cet. I, USA: The International Institute of Islamic Institute of Islamic Thought, 1430/2009.

Ali, A. Yusuf, The Holy Qur'an Text, Translation and Commentary, Riyad: Amana Corp, $1403 \mathrm{H}$.

Anonim, Encyclopaedia Britannnica, London: William Bentom Publisher, 1965.

Anwar, Syamsul, Hari Raya \& Problematika Hisab-Rukyat, cet. 1, Yogyakarta: Suara Muhammadiyah, 2008.

Anwar, Syamsul, Interkoneksi Studi Hadis dan Astronomi, cet. I, Yogyakarta: Suara Muhammadiyah, 2011.

AS Hornby, Oxford Advanced Learner's Dictionary of Current English, cet. 23 New York: Oxford University Press, 1986.

Aulawi, A. Wasit, Laporan Musyawarah Nasional Hisab dan Rukyat 1977, Jakarta: Ditbinbapera, 1977.

B. Lewis dkk, The Encyclopaedia of Islam, vol. III, Leiden: E.J. Brill, 1971.

Behbudi, Muhammad Baqir, The Quran A New Interpretation, terjemahan Collin Turner, cet. I, London: Curzon press, 1997.

Bin Baz, Abdullah, Kumpulan Fatwa Puasa, terjemahan Anshari Taslim dan E. Rukmana, Jakarta: Khairul Bayan, 2003.

Bîrûnî, al-, Abû Rayhan Muhammad ibn Ahmad, AlQânûn al-Mas'udî, di-tahqî̀q oleh 'Abd al-Karîm Sâmi al-Jundî, cet. I, Bayrût: Dâr al-Kutub al'Ilmiyyah, 1422/2002.

Departemen Agama RI, Al-Qur'an dan Tafsirnya, cet. I, Jakarta: Yayasan Penyelenggaraan Penterjemah/ Pentafsiran Al-Quran, 1975.

Fairuzzabadi, al-, Al-Qâmûs al-Muhit, Bayrût: Dâr alFikr, 1415/1995.

Fayad, Muhammad Muhammad, al-Taqwim, cet. II, alQâhirah: Nahdet Misr, 2003.

Ghârrî, al-, Ibrâhîm Hilmî, Al-Mawsî̀ah al-Falakiyyah, cet. I, Bayrût: Dâr al-Sharq al-'Arabî, 1429/2008.

Glasse, Cyril, Ensiklopedi Islam, terjemahan Ghufran A. Mas'adi, cet. II, Jakarta: PT Raja Grafindo Persada, 1999.

Guessoum, Nidhal, "Akhir al-Muqtarahat li $\underline{\text { Hall }}$ Mushkilât al-Taqwîm al-Islâmî”, dalam Nidhal Guessoum dan Mohammad Odeh, Applications of Astronomical Calculations to Islamic Issues, cet. I, Abu Dhabi: ICOP, EAS \& CDR, 2007.

Hadikusuma, Djarnawi, "Mengapa Muhammadiyah Memakai Hisab?", dimuat dalam Suara Muhammadiyah, No. I, Th. Ke-53, Dzulhijah 1392/ Januari 1973.
Haji Md. Khair Haji Md. Taib, Takwim Hijriah Khairiah, cet. I, Bangi: Penerbit Universiti Kebangsaan Malaysia, 1987.

Halbî, al-, Akram Hasan, al-Taqwim Dirâsah li alTaqwim wa al-Târîkh, cet. I, Libanon: al-Masadir, 14311/1991.

Ibn Manzûr, Lisân al-Arabî, Mesir: al-Mu'assasah alMisriyyah, t.th.

Ibn Taymiyyah, Al-Radd 'ala al-Mantiqiyyîn, Bombay: Sharaf al-Dîn al-Kutubi wa Awladah, 1368/1949.

Ilyas, Mohammad, "The Danjon Limit of Lunar Visibility: A Re-Examination", dimuat The Journal of the Royal Astronomical Society of Canada, No. 77, tahun 1983.

Ilyas, Mohammad, Islamic Astronomy and Science Development Glorious Past Challenging Future, cet. I, Selangor Darul Ehsan Malaysia: Pelanduk Publication, 1996.

Jauhari, al-, Tantawi, Al-Jawâhir fi Tafsir al-Qur'ân alKarîm, Bayrût: Dâr al-Fikr, t.t, Juz 6.

M.M. Syarif (ed.), A History of Muslim Philosophy, Wiesbaden: Otto Harrassowitz, 1963, Vol. 1.

Madjid, Nurcholish, "Ibn Taymiyya on Kalam and Falsafa (A Problem of Reason and Revelation in Islam)", Chicago: A Dissertation Submitted to The Faculty of Division on The Humanities in Candidacy for The Degree of Doctor of Philosophy, 1984.

Majelis Tarjih dan Tajdid Pimpinan Pusat Muhammadiyah, Pedoman Hisab Muhammadiyah, cet. II, Yogyakarta: Majelis Tarjih dan Tajdid PP Muhammadiyah, 1430/2009.

Mu'min, Abdul Amir, Qâmûs Dâr al-'Ilm al-Falakî, cet. I, Bayrût: Dâr al-'Ilm li al-Malayin, 2006.

Musa Mohamad (ed.), Towards Implementation of $A$ Unified Islamic Calendar, cet. I, Penang-Malaysia: International Islamic Calendar Programme, 1998.

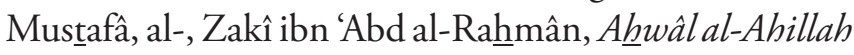
li 'Am 1431 H, cet. I, Riyâd: KACST, 1431/2010.

Nasution, Harun dkk, Ensiklopedi Islam Indonesia, cet. I, Jakarta: Djambatan, 1992.

PB NU, Pedoman Hisab dan Rukyat, Jakarta: Lajnah Falakiyah PB NU, 1994.

Qâdî̀, 'Adnân Abd al-Mun'im, Al-Ahillah Nazrah Shumuliyah wa Dirâsah Falakiyyah, cet. I, al-Qâhirah: Almasriah, 1426/2005.

Râzik, Jamâl al-din 'Abdur, al-Taqwim al-Qamarî alIslâmî al-Muwahhad, Rabat: Marsam, 2004.

Sa'b, al-, Sâlih Muhammad, Al-Shuhûr al-Qamariyah wa Tahdîd Bidayatuhâ, cet. II, Riyâd: KACST, 2010.

Saksono, Tono, Mengkompromikan Rukyat \& Hisab, cet. 1, Jakarta: Amythas Publicita, 2007.

T. Djamaluddin, Astronomi Memberi Solusi Penyatuan 
Ummat, Jakarta: LAPAN, 2011.

Zarqâ, al-, Mustafâ Ahmad, Al-'Aql wa al-Fiqh fi Fahm al-Hadith al-Nabawî, cet. I, Damaskus: Dâr alQalam, 2004.

\section{Website:}

"Pemerintah Putuskan Idul Adha 17 November", dimuat Koran Tempo, Selasa, 9 November 2010.

Bisri, A. Mustafa, "Begitu Aja Kok Repot", dimuat harian Jawa Pos, Rebo Kliwon, 15 Maret 2000.

\section{Media Massa dan Makalah:}

Ahyaie, Mashallah Ali, "Contradictions in Taghwim Recent Past and Present", makalah dipresentasikan pada The 20 th International Congress of History of Science, Belgia, 20-26 Juli 1997.
Azhari, Susiknan, "Kebersamaan Idul Fitri 1429", dalam harian Republika, Jumat, 26 September 2008.

--.---.--, "Penentuan Awal Ramadan dan Syawal Model Muhammadiyah", dimuat dalam Suara Muhammadiyah, No. 23 Th. Ke-85.

Bin Nuh, Abdullah, "Hanya Ada satu Djalan Bagi Umat Islam seluruh Dunia untuk Bersatu dalam Memulai dan Mengachiri Ramadan dan Menentukan Hari Raja Idul Fitri dan Idul Adha”, dalam Al-Jamiah, 5-6/Sept-Nov/1967.

Media Indonesia, Jumat, 2 September 2011.

Media Indonesia, Sabtu, 3 September 2011.

Purwanto, Agus, "Sidang Itsbat sudah Tidak Relevan", dimuat dalam majalah Suara Muhammadiyah, No. 19/ Th. Ke-96, 1-15 Oktober 2011.

Shaukat, Khalid. "A Suggested Global Islamic Calendar", dimuat dalam http://www.moonsighting.com, diakses 23 Oktober 2011, pukul 11.57 WIB. 